\title{
PELATIHAN PENYUSUNAN GUIDE BOOK POKDARWIS TUNJUNG MEKARDI DESA SAMBANGAN
}

\author{
oleh, \\ Dini Andiani \\ Fakultas Ekonomi dan Bisnis \\ Universitas Pendidikan Ganesha
}

\begin{abstract}
ABSTRAK
Kegiatan Pengabdian Pada Masyarakat (P2M) yang dilaksanakan ini bertujuan untuk memberikan pelatihan pembuatan guide book yang akan mampu memudahkan para anggota POKDARWIS untuk menjadi pemandu wisata yang bisa memberikan informasi yang tepat mengenai kondisi jalur trekking dalam bahasa inggris. Melalui kegiatan ini, anggota POKDARWIS memiliki acuan untuk menjadi guide lokal yang profesional. Metode yang digunakan dalam Program Pengabdian pada Masyarakat ini adalah metode kerja kolaborasi antara dosen, dan masyarakat sasaran (dalam hal ini adalah anggota POKDARWIS Tunjung Mekar). Di samping itu, dalam melaksanakan Program Pengabdian pada Masyarakat ini, pada awalnya dilakukan analisis situasi melalui beberapa kali observasi dan wawancara dengan pihak mitra, beberapa metode yang digunakan dalam melaksanakan proram ini seperti metode penyuluhan dan pelatihan, metode wawancara
\end{abstract}

Kata-kata kunci: pengabdian, quide book

\begin{abstract}
The community service activities are implemented aims to provide training on making guide book that will be able to facilitate the members Pokdarwis to be a tour guide who can provide precise information about the condition of trekking in English. Through these activities, members Pokdarwis has become a benchmark for professional local guide. The method used in this Community Service Program is a collaboration between lecturers working methods, and audience (in this case was a member of Pokdarwis Alas Bloom). In addition, in carrying out this Community Service Program, initially conducted analysis of the situation through several times of observation and interviews with the partners, some of the methods used in carrying out this proram such as counseling and training methods, the method of interview.
\end{abstract}

Keywords: service, quide book 


\section{Pendahuluan}

Pengembangan potensi wisata sambangan telah ditindak lanjuti dengan memaksimalkan partisipasi berbagai stakeholders yang ada seperti ; Adat, BPD, dan LPM. Realisasi dari pelembagaan itu, disepakati dengan menugaskan Made Widana sebagai Ketua POKDARWIS (Kelompok Sadar Wisata, yang di bentuk pada tahun 2004) untuk melakukan berbagai upaya memajukan dan mengembangkan potensi wisata yang ada. POKDARWIS di Desa Sambangan yang beranggotakan 30 orang termasuk pihak penanggung jawab dan penasehat di dalamnnya, rata rata memiliki jenjang pendididikan sampai tingkat SMU.

Pada hakikatnya dengan tingkat pendidikan yang baik, kepengurusan Kelompok Sadar Wisata yang di beri nama POKDARWIS Tunjung Mekar memiliki SDM yang baik harus mampu mengelola potensi. Namun pengelolaan tidaklah cukup hanya pada penataan objek wisata di lapangan, akan tetapi harus ada kemampuan di tingkat keterampilan dalam mendesign produk wisata dengan konsep pemetaan yang jelas, sehingga mampu menghasilkan peta paket wisata trekking yang lain dari pada yang lain, dan mampu menarik minat wisatawan untuk menyaksikan keunikan potensi alam yang dimiliki Desa Sambangan melalui penyelenggaraan kerjasama dengan beberapa travel agent yang bisa mendatangkan wisatawan. Kedua program pelatihan dan pembinaan pembuatan peta paket wisata dan pembuatan surat kerjasama dengan pihak BPW telah dilakukan di tahun 2011 dan tahun 2012. Dengan pelatihan pembuatan media promosi berupa peta design paket wisata yang unik dan tepat yang telah termuat dalam brosur pada saat program P2M 2011, yang memaparkan secara jelas kegiatan apa saja yang bisa dilakukan oleh wisatawan dan jangka waktu yang diperlukan wisatawan jika melakukan kegiatan tersebut. Serta melalui pelatihan pembuatan MOU saat program DIPA 2012 yang telah mampu menyaring kunjungan wisatawan dengan melakukan kerjasama dengan pihak Badan Penyelenggara Wisata atau BPW. Maka untuk peningkatan pengetahuan dan peningkatan kesiapan POKDARWIS Tunjung Mekar saat menerima kedatangan tamu, Kelompok POKDARWIS merasa perlu mendapatkan pelatihan bahasa inggris serta pembinaan pembuatan guiding book dan penyempurnaan kembali video treking yang sempat dibuat pada tahun 2011. Hal ini dirasa sangat perlu dalam rangka meningkatkan kesiapan para pemandu wisatawan yang masih memiliki 
kekurangan dalam melayani wisatawan terutama saat berkomunikasi dengan menggunakan bahasa inggris secara lebih profesional sehingga tidak terjadi kesalahpahaman dan wisatawan tidak merasa dirugikan nantinya.

Pentingnya kelembagaan POKDARWIS Tunjung Mekar ini sangat dirasakan oleh masyarakat Desa Sambangan, karena melalui kegiatan yang dilakukan dalam mengembangkan potensi alam desa yang ada, memberikan peluang kepada masyarakat untuk bertindak sebagai aktor dalam pengelolaan objek daya tarik wisata yang ada di desanya, baik itu untuk tempat trekking ataupun wisata spiritual melalui meditasi. Eksistensi pokdarwis Tunjung Mekar terhadap lingkungan wisata alam di Desa Sambangan.

Secara struktural jumlah anggota POKDARWIS berjumlah 30 orang, namun yang aktif dalam berbagai kegiatan pelaksanaan secara teknis dilapangan hanya 20 orang saja. Dapat diketahui pada tabel 1.2 hanya 4 orang yang mampu menguasai bahasa asing (bahasa inggris) dan hanya 2 orang yang memiliki keterampilan dalam menggunakan media elektronik yaitu computer. Tabel 1.1

Daftar nama-nama anggota POKDARWIS Yang memiliki kemampuan khusus

\begin{tabular}{|l|l|l|l|}
\hline No & \multicolumn{1}{|c|}{ Nama } & Nama Keahlian & Komputer \\
\cline { 3 - 4 } & & & Bahasa Inggris \\
\hline 1 & Darmada & Komputer dan Bahasa Inggris \\
\hline 2 & Komang Roy & Komputer dan Bahasa Inggris \\
\hline 3 & Putu Bayu Prasetya & Bahasa Inggris \\
\hline 4 & Kadek Adi Sucipta & Bahasa Inggris \\
\hline
\end{tabular}

Adapun tingkat jumlah kunjungan wisatawan ke Desa Sambangan yang ditangani langsung oleh anggota POKDARWIS Tunjung Mekar dapat dilihat pada tabel 1.2

Tabel 1.2

Rekapitulasi Perkembangan Kunjungan Wisman dan Wisdom Pada Objek dan Daya Tarik Air Terjun di Desa Sambangan Tahun 2008-2012

\begin{tabular}{|l|c|c|c|c|}
\hline \multirow{2}{*}{ No } & Tahun & \multicolumn{3}{|c|}{ Jumlah Kunjungan } \\
\cline { 3 - 5 } & & $\begin{array}{c}\text { Wisatawan } \\
\text { Mancanegara }\end{array}$ & $\begin{array}{c}\text { Wisatawan } \\
\text { Domestik }\end{array}$ & Jumlah \\
\hline 1 & 2008 & 178 & 509 & 687 \\
\hline
\end{tabular}




\begin{tabular}{|l|c|c|c|c|}
\hline 2 & 2009 & 177 & 489 & 666 \\
\hline 3 & 2010 & 222 & 107 & 329 \\
\hline 4 & 2011 & 256 & 73 & 359 \\
\hline 5 & 2012 & 278 & 793 & 1071 \\
\hline
\end{tabular}

Sumber : Data Olahan Dari POKDARWIS Tunjung Mekar, 2013

Tabel 1.3 menunjukan bahwa tingkat kunjungan wisatawan mengalami tingkat fluktuasi, pada tahun 2008 menunjukan tingkat kunjungan dari wisatawan domestik yang memiliki perbandingan signifikan dengan kedatangan tamu mancanegara, karena wisatawan domestik yang kebanyakan datang berkunjung adalah berasal dari sekolahsekolah serta dari aktivis pencinta alam. Kondisi tersebut menunjukan bahwa pihak pengelola belum mampu melakukan kegiatan promosi baik itu dalam rangka meningkatkan tingkat kunjungan wisatawan domestik ataupun wisatawan mancanegara. Tingkat kunjungan yang rendah yang dialami oleh kelompok POKDARWIS Tunjung Mekar disebabkan oleh (1) tingkat pengetahuan dan kemampuan dalam melakukan kerjasam dengan pihak BPW belum pernah dilakukan, (2) Kurangnya media promosi visual seperti video dan website, (3) tidak memiliki buku panduan (guiding book) dalam bahasa inggris, (4) belum memiliki pengetahuan tentang pengemasan produk paket wisata alternative.

Berdasarkan uraian tersebut di atas, maka jenis pelatihan yang mendasar yang di berikan adalah pelatihan pembuatan buku panduan atau guiding book yang mampu mengarahkan wisatawan asing dengan baik saat mereka mengikuti kegiatan treking dan di ikuti dengan pembinaan dalam pembuatan media audio visual berupa video potensi, sehingga nantinya mampu menghasilkan peningkatan kunjungan melalui kerjasama dan media promosi yang profesional.

Berdasarkan analisis situasi pada POKDARWIS di Desa Sambangan ada beberapa hal yang dianggap masih menjadi masalah dalam memajukan daya tarik wisata yang ada seperti; (a) Kemampuan melakukan promosi baik itu melalui kerjasama dengan industri industri pariwisata lainnya masih sangat rendah. Oleh karena dengan pelatihan pembuatan surat kontrak yang telah dilaksanakan, pelatihan lebih lanjut mengenai strategi promosi pada masing masing instansi terkait bisa di lakukan lagi, (b) Terkait dengan memberikan kepuasan terhadap wisatawan dan pihak BPW, POKDARWIS merasa perlu mendapat pembinaan dalam membuat video objek dan atraksi, sehingga mampu memberikan informasi yang objektif terhadap wisatawan dan pihak BPW pada 
saat melakukan perjanjian kerjasama, (c) Terkait dengan memberikan kepuasan terhadap wisatawan, POKDARWIS merasa kesulitan dalam memandu wisatawan, hal ini disebabkan karena anggota POKDARWIS merasa belum mampu dalam memberikan informasi terhadap wisatawan, sehingga mereka berharap bisa memiliki buku panduan (guiding book) dalam bahasa inggrisyang berisikan tahapan yang harus dijelaskan kepada wisatawan serta informasi detail tentang objek atau daya tarik yang ada di Desa Sambangan. Permasalahan mitra ini memerlukan tindak lanjut agar segera penyusunan buku panduan wisata ini bisa dipergunakan bagi para guide lokal. Justifikasi permasalahan prioritas yang di hadapi oleh mitra (POKDARWIS Tunjung Mekar) Berdasarkan kondisi empiris yang telah disebutkan, maka permasalahan pokok yang menjadi prioritas utama yang hendak diurai melalui program ini adalah: (a) Meningkatkan kualitas pelayanan wisata dengan memberikan pelatihan dalam penyusunan buku panduan wisata ini bisa dipergunakan bagi para guide lokal di lingkungan POKDARWIS Tunjung Mekar. Guide book tersebut berisikan tahapan yang harus dijelaskan kepada wisatawan serta informasi detail tentang objek atau daya tarik yang ada di Desa Sambangan, (b) Permasalahan lainnya karena keterbatasan dana pada program P2M 2012 realisasi penyempurnaan pembuatan video belum bisa diselesaikan, hanya sebatas perancangan konsep video yang akan disajikan, sehingga dengan kegiatan P2M tahun 2013 pembuatan video potensi treking bisa diselesaikan.

Adapun tujuan kegiatan yang dimaksud adalah (1). Dengan kegiatan pelatihan yang diberikan, anggota POKDARWIS Tunjung Mekar bisa menghasilkan suatu buku panduan wisata atau guide book dalam bahasa indonesia dan bahasa Inggris. Guide book ataupun buku panduan yang dihasilkan akan memberikan kemudahan bagi para guide lokal di lingkungan POKDARWIS Tujung Mekar, selain itu pula penjelasan yang di sampaikan pada wisatawan akan lebih terarah dan mencerminkan tingkat profesionalitas anggota POKDARWIS dalam memberikan informasi pada wisatawan yang mengikuti kegiatan treking, (2). Dengan pendampingan pembuatan video singkat sebagai media audio visual, dapat menunjang sarana komunikasi dan informasi baik untuk wisatawan dan pihak agen, sehingga kita menjual produk wisata yang nyata. Melalui pembinaan dan pendampingan ini akan menghasilkan kepingan cd yang berisikan video paket wisata yang menarik. 


\section{Metode Pelaksanaan Pengabdian}

Adapun beberapa metode kegiatan yang telah dipakai dalam pelaksanaan realisasi kegiatan P2M peningkatan kemampuan penggunaan ilmu bahsa komunikasi oleh kelompok POKDARWIS di Desa Sambangan Kecamatan Sukasada Kabupaten Buleleng, maka metode yang telah tepat untuk merealisasikannya adalah dengan (1) memberikan pemahaman lebih dalam tentang pentingnyal dan manfaat adanya buku panduan wisata atau guide book baik bagi para guide local dan wisatawan, (2) memberikan pengenalan tentang penyusunan guide book, (3) pelatihan aplikasi pembuatan guide book, (4) pendampingan implementasi pembuatan sesuai dengan aspek yang akan dimasukan dalam buku panduan wisata tersebut, (5) melakukan pembinaan mengenai pentingnya bahasa inggris dan realisasi pembuatan video sebagai media pendukung kegiatan promosi, (6) melakukan refleksi kembali serta penyempurnaan terhadap program yang telah dibuat yang akan ditindak lanjuti dengan menyeleksi beberapa anggota yang selama pelatihan memiliki kemampuan maksimal untuk mampu bertindak menangani perjanjian dan mengelola media promosi berupa video yang akan digabungkan dalam sales kit promotion.

Berdasarkan analisis situasi yang dipaparkan dan permasalahan yang dihadapi oleh pihak POKDARWIS, maka program ini telah difokuskan pada upaya peningkatan keterampilan pengelola POKDARWIS Tunjung Mekar yang beranggotakan 30 orang yang telah terbagi dalam dua kelompok utama yaitu Kelompok pengelola objek air terjun aling aling dan Kelompok pengelola objek air terjun Cemare di dalam membuat guide book sehingga berguna untuk kepentingan kelompoknya dalam memenuhi kebutuhan informasi wisatawan. Pemberian pelatihan ini hanya akan di ikuti oleh 17 orang anggota POKDARWIS saja, adapun beberapa jumlah anggota yang akan mendapat pelatihan tersebut telah tampak pada table 3.1.

Tabel 2.1.

Nama Anggota POKDARWIS Tunjung Mekar Peserta P2M

\begin{tabular}{|c|c|c|}
\hline No & Nama & Pendidikan Terakhir \\
\hline 1 & Komang Roy Prismayudi & SMU \\
\hline 2 & Putu Bayu Prasetya & SMP \\
\hline 3 & Putu Puspa & SMP \\
\hline 4 & Ketut Reksadana & SMU \\
\hline 5 & Made Sutama & S \\
\hline
\end{tabular}




\begin{tabular}{|c|c|l|}
\hline 6 & Mudiasta & SMU \\
\hline 7 & Kadek Pancadana & SMU \\
\hline 8 & Ketut Sugiarta & SMU \\
\hline 9 & Dedy Sastrawan & SMU \\
\hline 10 & Ketut Redana & SMU \\
\hline 11 & Ketut Sui Eka Budi & SMU \\
\hline 12 & I Gede Egy Yudha Pratama & SMU \\
\hline 13 & Putu Alit Juliarta & SMU \\
\hline 14 & Gede Putrawan & SMU \\
\hline 15 & Kadek Susila & SMU \\
\hline 16 & Putu Sony Suryanata & SMU \\
\hline 17 & Putu Darmawan & SMU \\
\hline
\end{tabular}

Sumber: POKDARWIS Tunjung Mekar, 2013.

\section{Hasil dan Pembahasan}

Lokasi mitra yaitu Kelompok Sadar Wisata POKDARWIS Tunjung Mekar berlokasi di Desa Sambangan terletak di Kecamatan Sukasada Kabupaten Buleleng. Desa ini dapat ditempuh dari Denpasar melalui jalur jurusan Bedugul terus melewati Sambangan, terminal Sukasada (terminal Sangket) masuk menuju kebarat menuju ke arah Desa Sambangan, yang ditempuh dalam waktu sekitar 2,5 jam. Program kegiatan pelatihan yang dilakukan merupakan realisasi dari hasil diskusi awal dengan rekan mitra yaitu ketua kelompok POKDARWIS Komang Roy Prismayudi dan wakil ketua Putu Doglas, maka realisasi pada kegiatan awal tim penyelengara datang kelokasi dan berdikusi mengenai aspek aspek yang akan dituangkan dalam buku guide book.

Penyelenggaraan kegiatan Pengabdian Pada Masyarakat melalui pemberian pelatihan keterampilan pembuatan guide book pada POKDARWIS di Desa Sambangan telah diselenggrakan oleh ketua beserta tim, yang berasal dari Jurusan Perhotelan jurusan dengan kosentrasi dibidang pariwisata khususnya bagian perencanaan pengembangan ODTW (Nyoman Dini Andiani M.PAR), bersama dua orang anggota pelaksana yaitu Master Linguistik Bahasa Inggris AA. Ngrh Yudha Martin dan Prabawati M.Hum. Anggota tim pengusul yang berasal dari disiplin ilmu pariwisata dan ilmu bahasa Inggris telah sangat bersinergi dalam melakukan pelatihan keterampilan penyusunan guide book. Adapun kelengkapan biodata tim pengusul dapat dilihat pada lampiran. 
Pelaksanaan Kegiatan dari awal sosialisasi program, diberikan pada bulan pertama dan bulan kedua, melalui cara awal terlebih dahulu yaitu pemberian pentingnya pemahamann terhadap peningkatan kemampuan dan pemberian informasi yang benar dengan bahasa yang tepat. Serta secara bersama sama terjun ke lokasi untuk melakukan pendataan secara terperinci mengenai data-data yang bisa mendukung pembuatan guide book tersebut. Sedangkan pemberian pembekalan mengenai beberapa hal yang bisa digunakan sebagai bahan dalam penyusunan guide book dari data yang diperoleh telah dilakukan pada bulan ketiga.

Penerapan program pelatihan yang telah dirancang telah dilakukan di base camp ataupun kantor POKDARWIS Tunjung Mekar Sendiri, selama penerapan program pelatihan baik yang dilakukan secara bersama sama dalam suatu ruangan, ataupun pada saat observasi di lapangan dalam pengumpulan data yang nantinya akan dimasukan dalam guide book. Pelatihan dalam pembuatan guide book yang sesuai dengan ketentuannya akan didampingi dan diberikan langsung oleh Tim Dosen. Penerapan program pelatihan ini, dilakukan berdasarkan analisis situasi yang dipaparkan dan permasalahan yang dihadapi oleh pihak POKDARWIS, maka program telah difokuskan pada upaya peningkatan kemampuan anggota dan pengelola POKDARWIS Tunjung Mekar yang beranggotakan 30 orang yang telah terbagi dalam dua kelompok utama yaitu Kelompok pengelola objek air terjun aling aling dan Kelompok pengelola objek air terjun Cemare di dalam menggunakan bahasa inggris saat memandu wisatawan dengan adanya guide book yang dihasilkan saat pelatihan. Pemberian pelatihan pembuatan guide book ini hanya dihadiri oleh 15 orang anggota, dan kurang dari rancangan awal sebelumnya yang dirancang akan bisa diikuti oleh 17 orang anggota POKDARWIS.

Beberapa penerapan program kerja yang telah dilakukan sesuai dengan rancangan awal pada kegiatan awal tim penyelengara telah datang ke lokasi dan melakukan pengamatan objek, sebagai bahan pembuatan media promosi. Upaya untuk memperkenalkan berbagai objek dan atraksi yang dapat dinikmati oleh wisatawan dan dapat dilakukan di objek akan dituangkan dalam pemetaan yang akan telah di rancang. Selanjutnya ceramah ataupun pembekalan berupa pemahaman mengenai pentingnya teknologi sebagai penunjang pembuatan media promosi telah pula dilakukan, namun 
tidak sesuai dengan rancangan awal sebelumnya yaitu dilakukan dalam ruang kelas, akan tetapi kegiatan ceramah ini dilakukan di pelataran start area jalur trekking bersama seluruh keanggotaan yang hadir saat itu, alas an pemilihan di ruang terbuka merupakan saran dari ketua POKDARWIS yang baru menjabat, guna meningkatkan rasa kebersamaan, dan menciptakan suasana yang yang lebih santai dan lebih kekeluargaan.

Partisipasi mitra yaitu anggota POKDARWIS dalam pelatihan dengan jumlah peserta pelatihan yang menyusut lagi 5 orang, sehingga bukan lagi peserta pelatihan 17 orang, akan tetapi menjadi 15 orang. Tingkat evaluasi keberhasilan kegiatan pelatihan pembuatan guide book yang dilakukan pada kelompok sadar wisata Tunjung Mekar di Desa Sambangan, dari tim pelaksana, telah menganggap bahwa dari proses awal sosialisasi sampai pada tahap penerapan pelatihan, dari anggota POKDARWIS memiliki antusias yang cukup tinggi dalam menyimak serta melakukan tahapan-tahapan pelatihan yang diberikan. Sesuai dengan target luaran yang diharapkan, telah tersususn suatu buku panduan dalam bahasa inggris yang fungsinya untuk memandu wisatawan asing yang di dalamnya berisi tahapan-tahapan percakapan yang mungkin ditanyakan oleh para wisatawan asing, dari percakapan di short treking, medium treking dan long treking, adapun target luaran yang telah dihasilkan tersebut dapat dilihat pada lampiran

Pemberian pelatihan penyusunan guide book bagi Kelompok Sadar Wisata Tunjung Mekar, memerlukan perhatian lebih lanjut. Adapaun beberapa identifikasi permasalahan yang masih dihadapi mitra, terlepas dari penyusunan guide book antara lain: (a) Kemampuan melakukan promosi baik itu melalui kerjasama dengan industri industri pariwisata lainnya seperti travel agent dan hotel hotel baik itu di kawasan Bali Utara pada khususnya dan Bali pada umumnya masih sangat rendah. Oleh karena hal itu diperlukan pelatihan lebih lanjut mengenai strategi promosi pada masing masing instansi terkait, (b) Belum memiliki pengetahuan tentang pengemasan produk paket wisata alternative. Permasalahan ini muncul karena tingkat kreativitas pihak pengelola belum banyak tertuang dalam menciptakan paket wisata yang menarik, sehingga diperlukan pelatihan mengenai cara menciptakan paket wisata alternative, yang di sesuaikan dengan target market yang akan dituju, (c) Tidak memiliki produk asli daerah yang bisa di gunakan sebagai cendramata. Potensi yang dimiliki berupa hasil bambu ataupun hasil pangan yang ada di Desa Sambangan bisa menghasilkan sesuatu yang 
bernilai, namun tanpa adanya pelatihan pengembangan usaha dalam menciptakan souvenir bagi desanya, masyarakat Desa Sambangan belum memunculkan jiwa wirausaha dan kreativitasnya, (d) untuk peningkatan jumlah kunjungan wisata, maka POKDARWIS Tunjung Mekar memandang perlu untuk mendapatkan pendampingan dalam penyusunan website, produk website yang dihasilkan nantinya merupakan bagian dari promosi sehingga mampu diakses dari manapun, (e) Manajemen pengelolaan oleh pihak POKDARWIS dalam mengelola sistem pemasukan keuangan dan pengelolaan SDM sama sekali masih belum optimal, sehingga sering terjadi gesekan gesekan dan menyebabkan perselisihan antara anggota, sehingga dalam hal ini untuk kelanjutan program pelu dilakukan pelatihan manejemen keuangan dan manajemen sumber daya manusia.

\section{Penutup}

Penerapan program pelatihan ini, dilakukan berdasarkan analisis situasi yang dipaparkan dan permasalahan yang dihadapi oleh pihak POKDARWIS, maka program telah difokuskan pada upaya peningkatan kemampuan anggota dan pengelola POKDARWIS Tunjung Mekar di dalam menggunakan bahasa inggris saat memandu wisatawan dengan adanya guide book yang dihasilkan saat pelatihan. Tingkat evaluasi keberhasilan kegiatan pelatihan pembuatan guide book, telah menganggap bahwa dari proses awal sosialisasi sampai pada tahap penerapan pelatihan, dari anggota POKDARWIS memiliki antusias yang cukup tinggi dalam menyimak serta melakukan tahapan-tahapan pelatihan yang diberikan. Sesuai dengan target luaran yang diharapkan, telah tersususn suatu buku panduan dalam bahasa inggris yang fungsinya untuk memandu wisatawan asing yang di dalamnya berisi tahapan-tahapan percakapan yang mungkin ditanyakan oleh para wisatawan asing, dari percakapan di short treking, medium treking dan long treking.

\section{DAFTAR PUSTAKA}

Anonim. 2006. Data Monografi Desa dan Kelurahan Sambangan, Kabupaten Buleleng.

Dalem, A. A. G. R. 2004a. Merumuskan prinsip-prinsip dan kriteria ekowisata daerah Bali. Jurnal Lingkungan Hidup Bumi Lestari 4 (2) : 86 - 90 
Dalem, A. A. G. R. 2004b. Ekowisata dan agrowisata. Makalah disampaikan pada penataran Kelompok Sadar Wiasata Denpasar tanggal 25-31 Juli 2004. Sebagian besar isi makalah ini pernah disampaikan dalam seminar "Dengan Ekowisata Menuju Pembangunan Pariwisata Berkelanjutan" di Auditorium Universitas Udayana Denpasar, 29 Juni 2002.

Kartajaya, Hermawan. 2003. Marketing in Venus. Jakarta: PT Gramedia Pustaka Utama

Kotler, P \& Bowen, J.T. \& Makens J.C. 2006. Marketing for hospitality and tourism, Pearson Education, Inc., New Jersey.

Pendit, Nyoman. 1999. Ilmu Pariwisata sebuah pengantar perdana. Jakarta: PT. Pradnya Paramita.

STP Bali. 2000. Evaluasi Produk Wisata Air Terjun Sambangan Kecamatan Sukasada Kabupaten Buleleng Propinsi Bali. STP: Nusa Dua Bali

Sudibya, Bagus, 2003, Prospektif Agrowisata dan Ekowisata di Kabupaten Buleleng Propinsi Bali (Makalah ini disampaikan pada Seminar menjadikan Buleleng sebagai Daerah Tujuan Wisata Agrotourisme dan Ekotourisme pada tanggal 25 Agustus 2003). 